\title{
РЕЗУЛЬТАТЫ ИНТРОДУКЦИИ КЕДРОВЫХ СОСЕН В МАГАДАНСКОЙ ОБЛАСТИ
}

\author{
Докучаева В. Б., Докучаев Н. Е. \\ ФГБУН Институт биологических проблем Севера ДВО РАН, г. Магадан \\ E-mail: vbdok@ibpn.ru
}

\begin{abstract}
Приводятся данные об интродукции на юге Магаданской области кедровых сосен - сосны сибирской (Pinus sibirica Du Tour) и сосны корейской (P. koraiensis Siebold et Zucc.). В 2018 г. у сосны сибирской здесь впервые было отмечено образование мужских микростробил и женских шишек. Вступление дерева в генеративную фазу развития говорит об успешной акклиматизации данного вида сосны к местным условиям. Климатические изменения, наблюдаемые в последние десятилетия, обеспечили достаточно благоприятные условия для произрастания интродуцированных видов прямостоячих кедровых сосен на юге Магаданской области. Полученные результаты показывают, что в условиях Северного Приохотья возможно культивирование кедровых сосен и использование их в качестве декоративных посадок.
\end{abstract}

Ключевые слова: сосна сибирская, Pinus sibirica, сосна корейская, Pinus koraiensis, интродукция, семеношение, Северное Приохотье, Магаданская область.

DOI: $10.34078 / 1814-0998-2020-4-62-69$

\section{ВВЕДЕНИЕ}

Из трех видов кедровых пятихвойных сосен, естественным образом произрастающих на территории России, в природной флоре Магаданской области представлена лишь сосна стланиковая, или кедровый стланик (Pinus pumila (Pallas) Regel). Вместе с лиственницей Каяндера (Larix cajanderi Mayr) он входит в число основных лесообразующих пород региона. На эти два вида примерно в равном соотношении приходится $81 \%$ лесопокрытой площади области (Москалюк, 2014). Разнообразие хвойных региона дополняют ель сибирская (Picea obovata Ledeb.), произрастающая изолированно в нескольких пунктах на юге области, и можжевельник сибирский $(\mathrm{Ju}$ niperus sibirica Burgsd.) (Флора..., 2010).

В настоящее время в Магаданской области имеются также участки с искусственными насаждениями хвойных. Заниматься такими посадками здесь начали в 1946 г. Поначалу они носили эпизодический характер и широкого распространения не получили, возможно, по причине отрицательных результатов (Стариков, 1958). В 1952-1956 гг. в питомнике, заложенном Магаданским лесничеством в черте города, пытались вырастить сеянцы елей и сосны корейской (Pinus koraiensis Siebold et Zucc.), которые, однако, все погибли в течение ряда лет (Стариков, 1958).

(C) Докучаева В. Б., Докучаев Н. Е., 2020
Примерно в это же время не прижились обыкновенные сосны (Pinus sylvestris L.) и ели в дендрарии при местном краеведческом музее (Леонова, 1982).

Успешнее оказались интродукционные работы, проводившиеся в пос. Снежная Долина, pacположенном в долине р. Дукча в 20 км от побережья. От ветров и прямого влияния морского климата эта часть долины защищена Дукчинскими горами. В 1958 г. там, на площади 0.5 га, была заложена рощица $P$. sylvestris, сохранившаяся до сих пор. В 1961 г. в пос. Снежная Долина была образована Магаданская Лесная опытная станция (ЛОС) Дальневосточного научноисследовательского института лесного хозяйства. В 1960-1970-е гг. сотрудники станции неподалеку от сосновой рощи осуществили посадки разных видов елей. До настоящего времени на землях бывшего дендрария ЛОС сохранилось несколько обособленных групп елей. Большая их часть принадлежит ели европейской (Picea abies (L.) Karst), также есть деревья ели сибирской (P. obovata) и их естественных гибридных форм $(P . \times$ fennica (Regel) Kom.), а также ели аянской (P. ajanensis (Lindl. et Cord.) Fisch. ex Carr.) (Докучаева, Докучаев, 2015a).

В 1970-1980 гг. искусственные посадки хвойных пород на территории области приняли более планомерный и масштабный характер. В разных лесничествах продолжали высаживать сосну обыкновенную и ели. Отдельные участки с 
хвойными интродуцентами, созданными в 19501980 гг, сохраняются до настоящего времени (Докучаева, 2011, 2013, 2014; Докучаева, Докучаев, 2015a, б). К концу 1980-х гг, однако, лесокультурной деятельностью в Магаданской области практически перестали заниматься, за исключением высевания в ограниченных количествах семян лиственницы Каяндера.

Опыт по интродукции кедровых сосен в Магаданской области за рассмотренный период был весьма скромным. Кроме упомянутых неудачных попыток выращивания кедра корейского в 1950-е гг. в черте г. Магадана, культивированием кедровых сосен планировала заниматься и лесная опытная станция, первоначально располагавшаяся в пос. Ола. Семена «кедра» на станцию поступали из Якутии (Заполярная..., 1963), однако никаких данных о судьбе этого посадочного материала не сохранилось.

Сосна сибирская (Pinus sibirica Du Tour), иногда называемая сибирским кедром, считается одной из первых искусственно разводимых древесных пород в России. В европейской части страны она стала культивироваться со второй половины XVI в. (Игнатенко, 1988). На Дальнем Востоке обращение к этому виду для целей интродукции относится к началу ХХ в. О. В. Маркграф, обследовавший в 1911-1912 гг. обширную территорию в западной части Охотского побережья, в докладе на заседании Императорского Русского географического общества в апреле 1914 г. высказал смелую идею о желательности разведения в Приохотье кедра (вид не был указан) (Манько, 2012).

В настоящее время в Примагаданье вне населенных пунктов известно несколько мест произрастания кедровых сосен, распространению которых случайно или намеренно способствовал человек. Такие сосны можно видеть и на отдельных приусадебных и дачных участках жителей г. Магадана и ближайших к нему поселков. Цель нашего исследования - обобщить данные о кедровых соснах, произрастающих на территории Магаданской области, оценить их состояние и перспективность интродукции.

\section{МАТЕРИАЛ И МЕТОДЫ}

Всего нами были собраны данные о более 30 кедровых соснах, произрастающих в разных местах на побережье и ближайших окрестностях г. Магадана (рис. 1). Представлены они одиночными деревьями или в составе небольших групп. В основном это разного возраста сеянцы, имматурные и виргинильные особи, и только одно дерево достигло генеративного состояния. Большая часть интродуцентов относится к сосне сибирской. Принадлежность одного дерева к этому виду установлена по морфологическим особенностям шишек и орехов, а остальные были выращены из семян P. sibirica. Видовая принадлежность шести «кедров» осталась неизвестным.

Можно видеть (см. рис. 1), что кедровые сосны растут как непосредственно на побережье, так и на удалении 20 км от моря. Близость моря обеспечивает повышенную влажность воздуха и относительно низкие летние температуры. Зимние условия здесь гораздо мягче, чем в континентальных районах области. Так, по данным метеостанции «Магадан (Нагаева, бухта)», среднее годовое количество осадков здесь составляет 526 мм; относительная влажность воздуха в летние месяцы 83-85\%; средняя температура июля $+11.2^{\circ} \mathrm{C}$, января $-17.0^{\circ} \mathrm{C}$; средняя

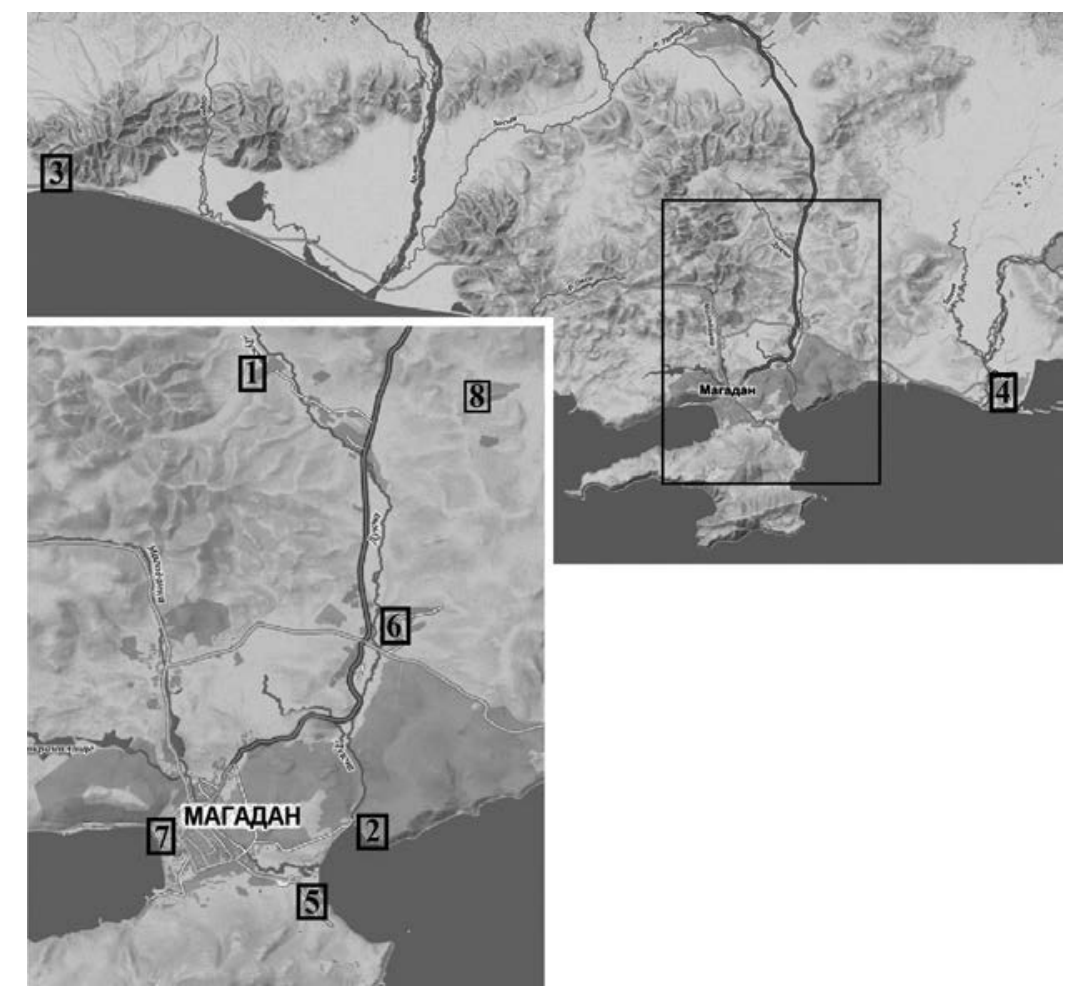

Puc. 1. Места произрастания кедровых сосен на побережье и ближайших окрестностях Магадана: 1 - пос. Снежная Долина; 2 - бух. Гертнера; 3 - пос. Янский; 4 - пос. Ола; 5 - Кедровый ключ; 6 - дачи на 14-м км; 7 - парк «Маяк»; 8 - «Орбита»

Fig. 1. Sites of cedar pines growing on the coast, and in the nearest vicinities of Magadan: 1 - Snezhnaya Dolina; 2 - Gertner Bay; 3 - settlement of Yansky; 4 - settlement of Ola; 5 - Kedrovy Klyuch; 6 - dachas on the $14^{\text {th }} \mathrm{km} ; 7$ - Mayak Park; 8 - "Orbita" 
продолжительность безморозного периода - 114 дней (Научно-прикладной..., 1990). Сумма средних суточных температур выше 5 и $10^{\circ} \mathrm{C}$ достигает 1075 и 690 градусов соответственно (Справочник..., 1966). Мерзлота носит островной характер.

У кедровых сосен, выбранных нами в качестве модельных (местоположения 1 и 2), начиная с 2008 г., ежегодно определяли высоту надземной части, протяженность кроны, диаметр стволов у поверхности земли и на высоте 130 см, а также длину побегов и величину приростов за 10 лет и более. Оценивали продолжительность жизни хвои и ее длину. Возраст надземной части растений определяли традиционным методом - подсчетом числа мутовок на стволе.

\section{РЕЗУЛЬТАТЫ И ОБСУЖДЕНИЕ}

Большая часть кедровых сосен, произрастающих в Магаданской области, представлена прямостоячими одноствольными деревьями. Встречаются и кустовидные экземпляры, формиру-

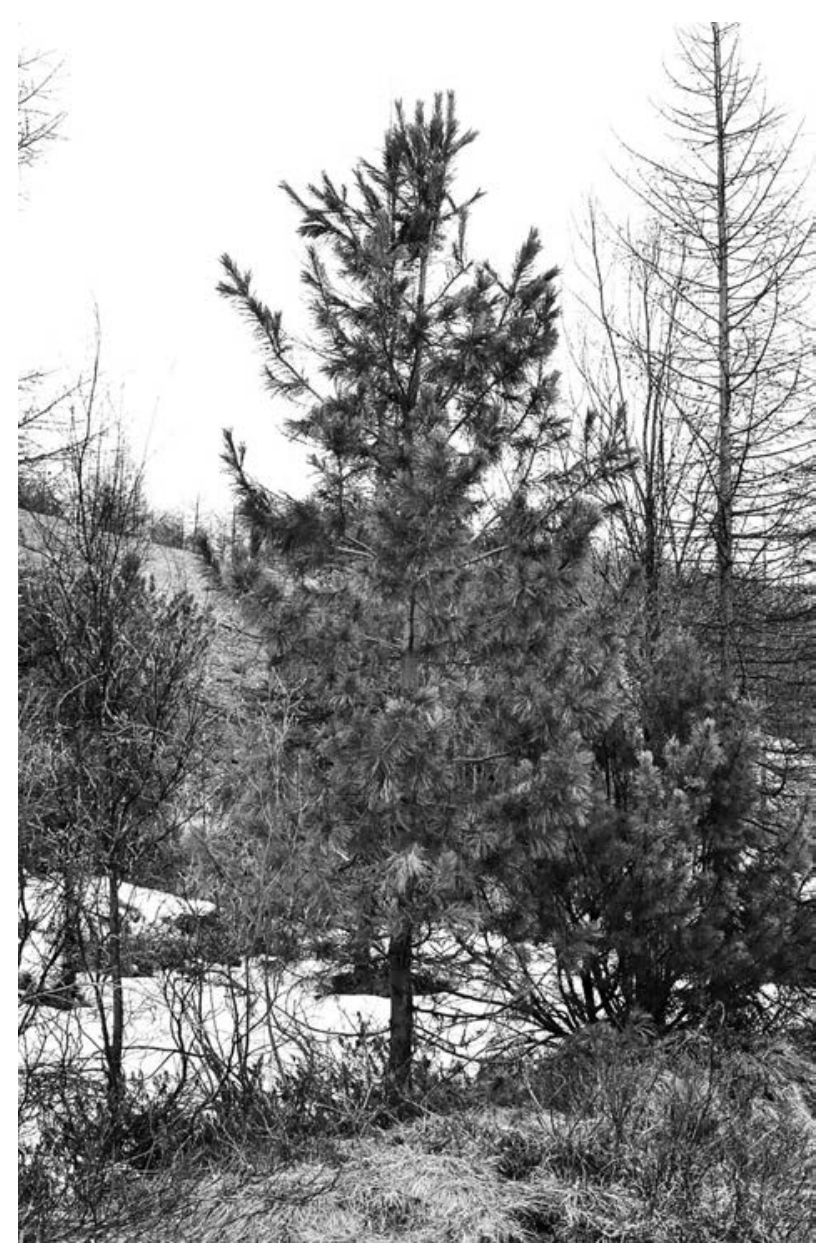

Puc. 2. Сибирская сосна в окрестностях пос. Снежная Долина (16 мая 2020 г.)

Fig. 2. Siberian pine in the vicinities of the Snezhnaya Dolina settlement (16 May, 2020) ющиеся в результате гибели или повреждения верхней части ствола. Сосна сибирская достаточно морозостойкая и морфологически пластичная в надземной и подземной частях, что позволяет ей расти в разных местообитаниях, отличаясь значительным формовым разнообразием по многим признакам (Крылов и др., 1983; Кедровые..., 1985; Данченко, Бех, 2010; Рысин, 2011).

В окрестностях пос. Снежная Долина (см. рис. 1, местоположение 1) в пойме руч. Артековский - правого притока р. Дукча, растет одиночное дерево сосны сибирской (рис. 2). На небольшом уступе у основания крутого откоса склонового шельфа в хорошо инсолируемом и защищенном от ветра месте складываются благоприятные условия для его произрастания. Почва суглинистая, свежая, дренированная. Прямоствольное, одновершинное дерево сосны в сентябре 2019 г. имело высоту 5.5 м, диаметр ствола на уровне груди - $12 \mathrm{~cm}$, у корневой шейки 13.5 см. Крона густая, низко опущенная, количество мутовок - 27. Хвоя длиной 10-12 см сохраняется 4-5 лет. Вблизи растут лиственницы, превышающие по высоте сосну, но не затеняющие ее, и чозении (Chosenia arbutifolia). В подлеске кедровый стланик, по бровке уступа: кусты жимолости (Lonicera coerulea), ив (Salix schwerinii, S. krylovii). В травяно-кустарничковом яруce: спирея березолистная, голубика, багульник болотный, брусника, иван-чай узколистный, осока. В мохово-лишайниковом ярусе преобладают зеленые мхи.

Сосна достигла генеративного возраста. Одновершинная крона дерева в 2017 г. немного изменила форму, стала больше куститься. В августе 2018 г. на сосне были обнаружены 5 женских шишек, сформированных на двух интенсивно растущих ветвях верхней мутовки, а на тонких осевых и боковых побегах среднего яруса кроны были обнаружены мужские колоски (микростробилы). Озимь в сентябре имела буроватокоричневую с фиолетовым оттенком окраску. В начале лета 2019 г. четыре шишки одновременно с ростом побегов увеличились в размере, пятая шишка оставалась маленькой и отличалась по цвету. 4 сентября 2019 г. шишки были сняты с дерева. Недоразвитая шишка оказалась высохшей, имела размер озими: 2 см в длину и $1.8 \mathrm{~cm} \mathrm{в}$ ширину. Рост ее остановился, так как опыленных семян, по-видимому, оказалось недостаточно для нормального развития. Остальные шишки имели темно-коричневую с фиолетовым оттенком окраску, были небольшого размера, округлой, немного несимметричной формы (рис. 3). Масса, размеры шишек и орешков приведены в таблице.

Число орехов в шишках варьировало от 12 до 46 шт. Их средний размер составил $11.2 \pm 0.05 \times$ 
$8.3 \pm 0.07$ мм $(\mathrm{n}=117)$, а масса 100 орехов в среднем 38.7 г.

Хотя внешне орехи выглядели нормально развитыми, большая их часть оказалась без ядер (пустыми). С ядрами было лишь $10.7 \%$ орехов.

Вступление сосны в генеративный период произошло в возрасте примерно 35-40 лет, если учитывать количество мутовок ветвей главного ствола и предполагать, что период развития сеянца в достаточно благоприятных условиях развития данного дерева мог составлять 5-10 лет или больше. Летом 2019 г. на этой сосне были обнаружены только мужские колоски с пыльниками. Шишки женской генерации не заложились.

В основании крутого приморского склона юго-западной экспозиции бух. Гертнера (см. рис. 1, местоположение 2) росло стройное деревце кедровой сосны (рис. 4,a). Под защитой камней и густых зарослей растущих поблизости ольховника (Duschekia fruticosa (Rupr.) Pouzar) и березы шерстистой (Betula lanata (Regel) V. Vassiljev) прямоствольное островершинное деревце хорошо развивалось. В период с 2008 по 2014 г. значительно увеличились приросты главного побега, высота дерева с 1.5 м достигла 2.4 м, диаметр в основании ствола -9 см. Примерный возраст его составлял 20-25 лет. В конце декабря 2014 г. дерево было варварски спилено. После удаления верхней части ствола остался пенек высотой около 80 см. Ветви сохранившихся пяти нижних мутовок продолжили рост. Восстановление кроны пошло за счет развития вторичных ветвей. Сосна приобрела кустовидную форму роста. В 2016 г. отрастающие побеги ветвей верхней мутовки изменили направление роста на ортотропное. Горизонтальные участки ветвей достигли длины 50-60 см. Общая высота растения в настоящее время составляет $191 \mathrm{~cm}$, «пенек»$87.5 \mathrm{~cm}$, диаметр в основании ствола - 11 см (рис. $4, \sigma)$. В дальнейшем при благоприятных условиях роста этот кедр может сформироваться как малоствольное дерево.

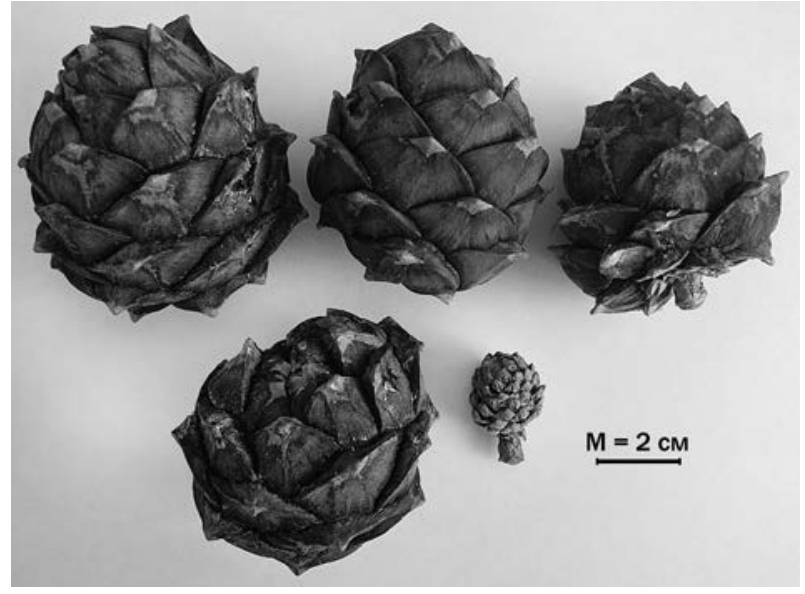

Pис. 3. Шишки «местной» сибирской сосны (4 сентября 2019 г.)

Fig. 3. Cones of the "local" Siberian pine (September 4, 2019)

Другая кедровая сосна росла там же, но выше по склону на 14 м. Почва хорошо дренированная, щебнистая. Первоначально эта сосна имела кустовидную форму роста (рис. 5,a), что, видимо, было сопряжено с суровыми условиями произрастания. В результате повреждения морозом наиболее уязвимых верхушечных точек роста несколько раз происходило обмерзание не успевших одревеснеть верхушечных побегов. Это провоцировало рост боковых почек, выполняющих функцию спящих, и происходило неоднократное перевершинивание. На момент обнаружения в 2008 г. куст имел высоту всего лишь 49 см и разреженную крону. По прошествии 7 лет растение все еще имело вид куста (рис. 5,a). В последующие годы обмерзания верхушки главного побега не наблюдалось, рост деревца улучшился, и среднегодовой прирост его главного побега составлял уже 12 см. К осени 2018 г. сосна достигла высоты 147 см, приобретя форму дерева с «юбкой» (рис. 5,б). В 2019 г. оно было выкопано неизвестными лицами.

Таблица. Масса и размеры шишек и орешков сибирской сосны, растущей в окрестностях пос. Снежная Долина

Table. Weight and size of cones and seeds of the Siberian pine growing in the vicinities of the Snezhnaya Dolina settlement

\begin{tabular}{|l|c|c|c|c|}
\hline \multirow{2}{*}{\multicolumn{1}{|c|}{ Показатель }} & \multicolumn{3}{c|}{ Шишка } \\
\cline { 2 - 5 } & № 1 & № 2 & № 3 & o 4 \\
\hline Масса шишки, г & 50.0 & 34.6 & 24.4 & 37.0 \\
\hline Длина по стержню, мм & 53.0 & 48.6 & 48.7 & 39.8 \\
\hline Длина максимальная, мм & 59.0 & 53.2 & 52.3 & 45.5 \\
\hline Диаметр шишки, мм & 61.0 & 51.8 & 53.0 & 56.0 \\
\hline Кол-во орехов, экз. & 46 & 29 & 12 & 30 \\
\hline Масса орехов, г & 18.0 & 11.0 & 4.6 & 11.7 \\
\hline Масса 100 орехов, г & 39.1 & 37.9 & 38.3 & 39.0 \\
\hline
\end{tabular}




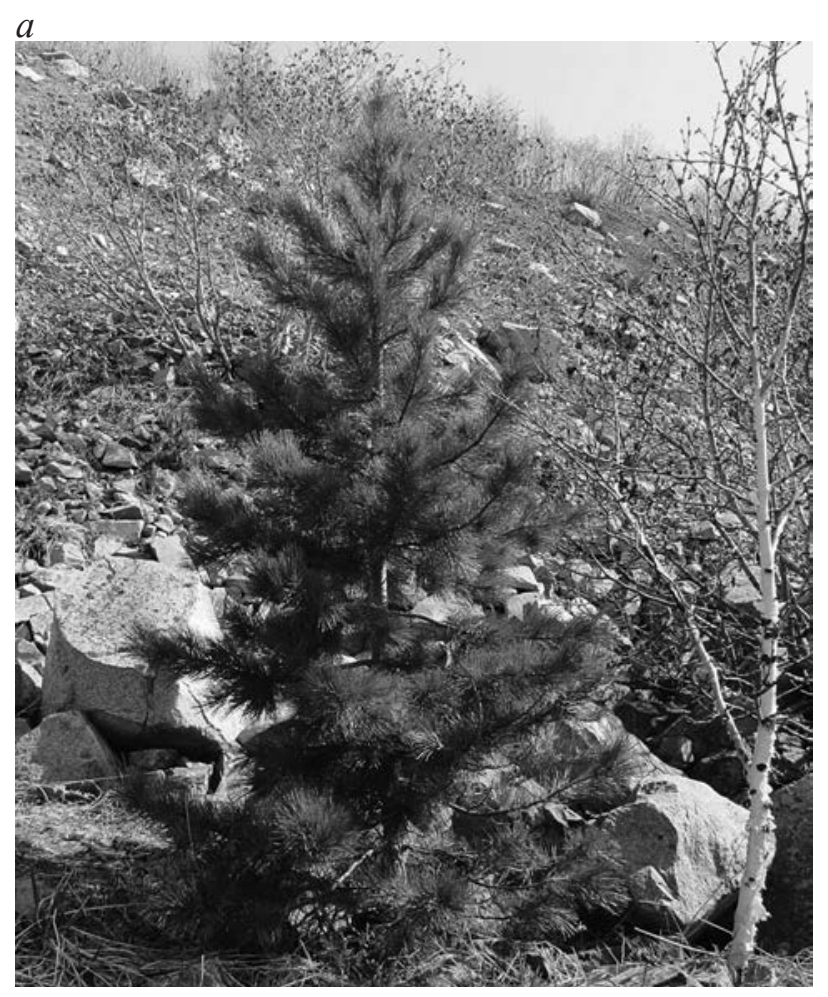

$\sigma$

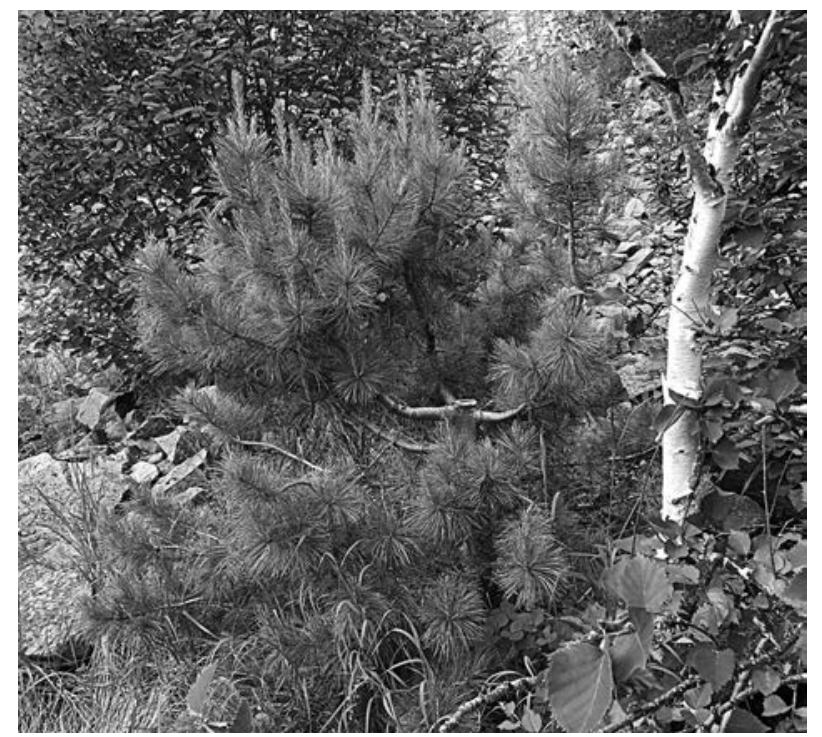

Рuc. 4. Кедровая сосна, растущая на побережье бух. Гертнера. До спиливания, 28.05.2011 г. (a); то же дерево, 5.07.2020 г. (б)

Fig. 4. Cedar pine growing on the coast of Gertner Bay. Before cutting, May 28, 2011 (a); same tree, July 5, 2020 (б)

Две кедровых сосны произрастают в окрестностях пос. Янский, расположенного на побережье Тауйской губы Охотского моря в 75 км к западу от Магадана (см. рис. 1, местоположение 3). Сосны находятся в 0.5 км от моря, в окружении зарослей ерника (Betula middendorffii Trautvetter et C. A. Meyer), с участием кедрового стланика высотой от 1 до $1.5 \mathrm{M}$, с отдельными невысокими деревцами лиственницы и березы шерстистой.
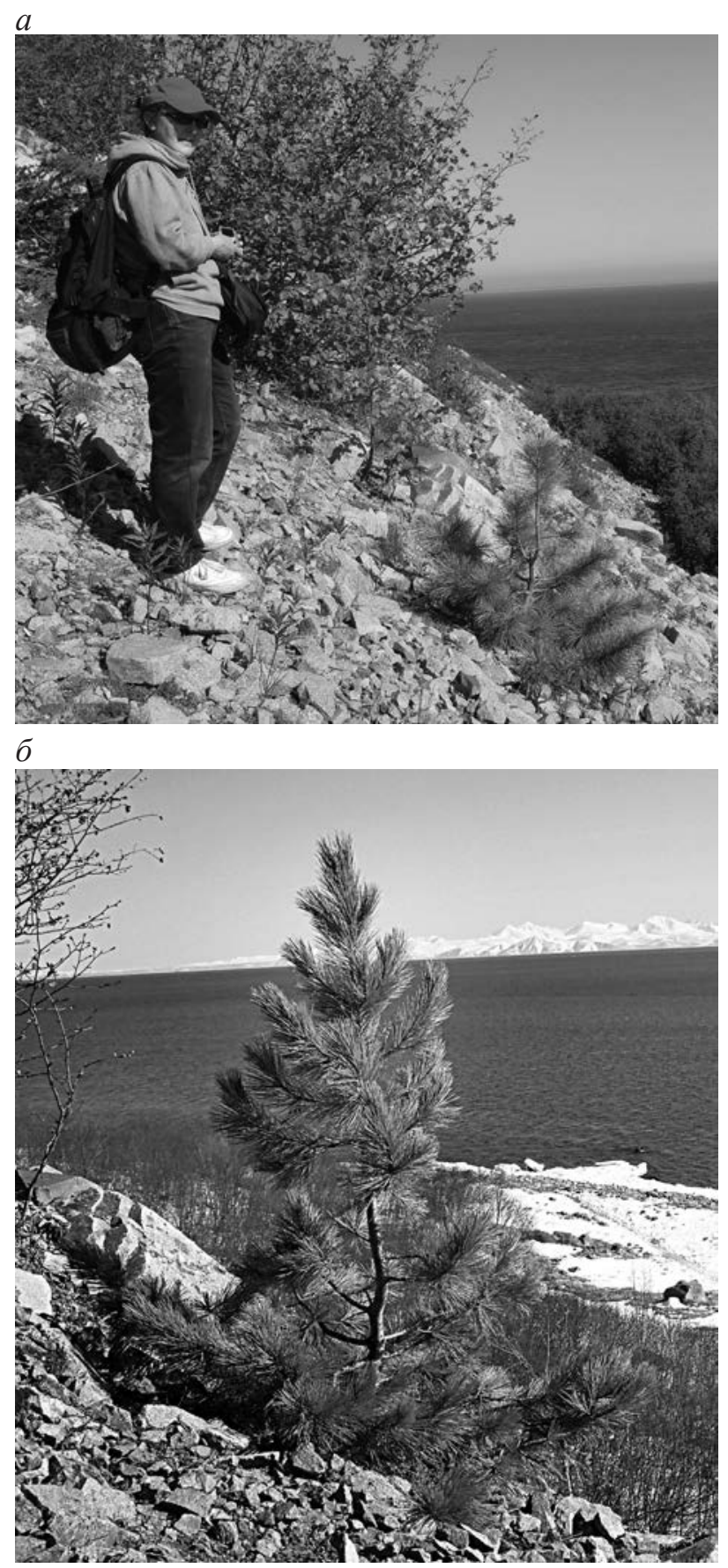

Puc. 5. Кедровая сосна, растущая на приморском склоне бух. Гертнера (в виде куста, 27.06.2015 г. (a); то же деревце через 4 года, 27.04.2019 г. (б)

Fig. 5. Cedar pine growing on the maritime slope of Gertner Bay (as a bush, June 27, 2015 (a); same tree after 4 years, April 27, 2019 (б)

Низменное открытое прибрежное пространство отличается сравнительно суровыми условиями для произрастания древесной растительности. Под воздействием ветра у многих растений сформировались флагообразные кроны. Одна из обнаруженных здесь кедровых сосен имеет кустовидную форму роста, мало отличаясь от произраставших поблизости кустов кедрового стланика. Высота ее - 1.5 м. В кроне выделяются два 
главных побега, один из которых немного отстает в росте. Имеются следы многократных обмерзаний верхушечных побегов. Вторая сосна имеет форму дерева, ствол которого был поврежден на высоте 75 см. Затем рост продолжили три компактно расположенные ветви, одна из которых также была недавно спилена. Высота этой сосны сенью 2019 г. составляла 2.15 м. Крона несимметричная, флагообразная. В отличие от кедровой сосны, растущей на берегу бух. Гертнеpa, по-видимому, повреждение верхушки ствола произошло у относительно молодой особи, и оставшийся пенек был небольших размеров.

В пос. Ола (см. рис. 1, местоположение 4) в 2013 г. во дворе одного частного дома нами было замечено деревце кедровой сосны. Высота его составляла примерно 1.7 м. Хозяин подворья сказал, что обнаружено и принесено оно было из леса вблизи поселка. Через 5 лет это деревце погибло.

В окрестностях Магадана на участках многих садоводов-любителей в настоящее время растут молодые деревца кедровых сосен. Так, в районе Кедрового ключа (см. рис. 1, местоположение 5) на одном из дачных участков растет одиночная кедровая сосна. В 2019 г. ее высота превысила 3 м, дерево имеет хорошее состояние хвои и кроны.

На трех дачных участках (см. рис. 1, местоположение 6), расположенных на левобережье p. Дукча в районе 14-го км Колымской трассы, также имеется несколько молодых сосен, выращенных из семян Pinus sibirica, привезенных из Новосибирска. Возраст пяти из них сейчас составляет примерно 20 лет. Это стройные, одноствольные, островершинные деревца высотой от 2.21 до 2.65 м. Там же на соседнем участке имеются два «кедра», выросших из семян сибирской сосны (урожая 2011 г.), посаженных в 2012 г. В возрасте 5 лет у обоих начала ветвиться главная ось. В настоящее время высота одного растения составляет $57 \mathrm{~cm}$, второго - $26 \mathrm{~cm}$.

Осенью 2019 г. семь саженцев сибирской сосны (высотой до 0.5 м) были посажены в недавно созданном на берегу бух. Нагаева парке «Маяк» (см. рис. 1, местоположение 7). Растения плохо перезимовали. В 2020 г. четыре из них находились в угнетенном состоянии, а три погибли.

По опросным данным, более 10 кедровых сосен растет на дачных участках в районе телевизионной станции «Орбита» (см. рис. 1, местоположение 8). Все деревца здесь принадлежат P. sibirica. Большая часть их выращена из орехов, а несколько в виде саженцев были привезены из г. Якутска. Жизненное состояние последних несравненно хуже.

Возникает вопрос, почему в 1940-1950-е гг. попытки выращивания кедровых сосен в Магаданской области терпели неудачу, а в 2019 г. на сибирской сосне здесь впервые созрели шишки?
Известно, что рост древесной растительности на северном пределе произрастания чутко реагирует на изменение летних температур. В западной и центральной частях Сибири, например, потепление, наблюдаемое в последние пять десятилетий, привело к увеличению сомкнутости вечнозеленых хвойных древостоев (сибирской сосныPinus sibirica, пихты - Abies sibirica, сосны обыкновенной - Pinus silvestris и ели - Picea obovata) на 15-50\% и смещению их северной границы распространения в северном направлении в среднем на 26 км (Им и др., 2020). В верховьях Колымы повышение среднегодовой температуры воздуха за 1991-2013 гг. составило $2.1^{\circ} \mathrm{C}$, а средней температуры теплого периода на $2.0^{\circ} \mathrm{C}$ (Синельникова, Пахомов, 2015). По данным этих авторов, существенно изменились и температурные характеристики вегетационного периода - суммы температур выше 0 и $5^{\circ} \mathrm{C}$ возросли на 174.5 и $184.6^{\circ} \mathrm{C}$ соответственно, а дата весеннего перехода среднесуточных температур через $5^{\circ} \mathrm{C}$ сместилась на более ранние сроки, составившие 10 дней. Благоприятные условия для вечнозеленых хвойных пород в эти годы складывались и в Северном Приохотье. Так, продолжительность вегетационного периода в Магадане с 1984 по 2013 г. в среднем увеличилась на 6 дней (Ушаков, 2017). Несомненно, все это положительно сказалось на интродуцированных в Примагаданье вечнозеленых хвойных породах, в частности, на сибирской сосне.

\section{ЗАКЛЮЧЕНИЕ}

Площади искусственных посадок вечнозеленых хвойных деревьев в Магаданской области ограничены. Отсутствие на территории Севера Дальнего Востока ботанических садов и дендрариев требует бережного отношения ко всем имеющимся здесь местам произрастания интродуцированных растений. По нашим данным, большая часть кедровых сосен, интродуцированных на территории Магаданской области, относится к сосне сибирской. Отмеченное семеношение $P$. sibiricus свидетельствует об успешной интродукции данного вида на территории Магаданской области. Характеризуясь большой морфологической пластичностью, значительной морозостойкостью, способностью расти на почвах с вечной мерзлотой, сосна сибирская относительно близка в экологическом и фенологическом отношениях к кедровому стланику, одному из главных лесообразующих пород нашего региона. Лишь видовая принадлежность шести кедровых сосен в местоположениях 2-5 (см. рис. 1) не была установлена. Учитывая неудачный опыт выращивания сосны корейской в 1950-е гг. на территории области, а также высокую требовательность это- 
го вида к условиям произрастания, неопределенные «кедры» скорее можно отнести к P. sibirica. Вопрос по выращиванию в Северном Приохотье P. koraiensis, таким образом, остается открытым.

Кедровые сосны, отличающиеся большой декоративностью, особенно интересны и перспективны для целей озеленения и развития лесопаркового хозяйства города Магадана. В частности, необходимо дальнейшее изучение биологических особенностей в новых условиях произрастания сосны сибирской как наиболее приспособленной к условиям нашего региона.

\section{БЛАГОДАРНОСТИ}

Сведения о местах произрастания кедровых сосен у пос. Янский и на двух дачных участках были любезно предоставлены О. Н. Вохминой, за что авторы ей весьма благодарны.

\section{ЛИТЕРАТУРА}

Данченко А. М., Бех И. А. Кедровые леса Западной Сибири. Томск : Томский гос. ун-т, 2010. 424 с.

Докучаева В. Б. О состоянии интродуцированных видов древесных растений в г. Магадане и его окрестностях // Геология, география, биологическое разнообразие и ресурсы Северо-Востока России : Материалы Дальневост. региональной конф., посвящ. памяти А. П. Васьковского и в честь его 100-летия (Магадан, 22-24 ноября 2011 г.). Магадан : СВНЦ ДВО РАН, 2011. C. 185.

Докучаева В. Б. Интродуцированные виды рода $\mathrm{Pi-}$ nus (Pinaceae) в Магаданской области // Тр. XIII съезда русского ботанического общества и конференции «Научные основы охраны и рационального использования растительного покрова Волжского бассейна» (Тольятти, 16-22 сент. 2013). Т. 3. Охрана растительного мира. Тольятти : Кассандра, 2013. С. 129 131.

Докучаева В. Б. Состояние культур сосны обыкновенной (Pinus sylvestris L.) в Магаданской области // Вестник Северо-Восточного научного центра ДВО РАН. 2014. № 2. С. 88-96.

Докучаева В. Б., Докучаев Н. Е. Виды елей в посадках в окрестностях г. Магадан // Вестник ДВО РАН. 2015a. № 5. C. 78-82.
Докучаева В. Б., Докучаев Н. Е. Состояние посадок елей в окрестностях г. Магадана // Вестник СевероВосточного научного центра ДВО РАН. 2015б. № 4. C. 67-75.

Заполярная ель поселится в Магадане // Маяк Севера : [газета], 19 мая 1963. № 71 (208).

Игнатенко М. М. Сибирский кедр (биология, интродукция, культура). Москва : Наука, 1988. 160 с.

Им С. Т., Харук В. И., Ли В. Г. Миграция северной границы вечнозеленых хвойных древостоев в Сибири в XXI столетии // Современные проблемы дистанционного зондирования Земли из космоса. 2020. Т. 17, № 1. C. 176-187.

Keдровые леса Сибири. Новосибирск : Наука, 1985. $258 \mathrm{c}$.

Крылов Г. В., Таланцеев Н. К., Козакова Н. Ф. Кедр. Москва : Лесная пром-сть, 1983. 216 с.

Леонова А. В. Ботанический сад музея // Краеведческие записки. Магадан : Кн. изд-во, 1982. Вып. 12. C. $210-219$.

Манько Ю. И. Оттон Маркграф - исследователь лесов Приохотья // Вестник ДВО РАН. 2012. № 6. C. $120-126$.

Москалюк T. А. Состояние и изученность лесов Магаданской области // Вестник Северо-Восточного научного центра ДВО РАН. 2014. № 1. С. 46-54.

Научно-прикладной справочник по климату СССР. Сер. 3. Многолетние данные. Части 1-6. Вып. 33. Магаданская область, Чукотский автономный округ Магаданской области. Ленинград : Гидрометеоиздат, 1990. 567 c.

Рысин Л. П. Кедровые леса России. Москва : Товво науч. изданий КМК, 2011. 240 с.

Синельникова Н. В., Пахомов М. Н. Сезонная жизнь природы Верхней Колымы. Москва : Тов-во науч. изданий КМК, 2015. 329 с.

Справочник по климату СССР. Вып. 33. Чукотский национальный округ и Магаданская область. Ч. II. Температура воздуха и почвы. Ленинград : Гидрометеорологическое издательство, 1966. 288 с.

Стариков Г. Ф. Леса Магаданской области. Магадан : Кн. изд-во, 1958. 224 с.

Ушаков М. В. Современные изменения термического режима в районе государственного природного заповедника «Магаданский» // Тр. Карельского науч. центра РАН, 2017. № 4. С. 93-98.

Флора и растительность Магаданской области (конспект сосудистых растений и очерк растительности). Магадан : ИБПС ДВО РАН, 2010. 364 с.

Поступила в редакичю 03.07.2020 г.

Поступила после доработки 14.09.2020 2.

\title{
RESULTS OF CEDAR PINES INTRODUCTION IN MAGADAN OBLAST
}

\author{
V. B. Dokuchaeva, N. E. Dokuchaev
}

\author{
Institute of Biological Problems of the North, FEB RAS, Magadan
}

Data on introduction of Siberian (Pinus sibirica Du Tour) and Korean (P. koraiensis Siebold et Zucc.) cedar pines in the south of Magadan Oblast are given. In 2018, male microstrobiles and female cones were formed on the Siberian pine for the first time here. The entry of the tree into 
the generative phase of development indicates a successful acclimatization of this species to the local conditions. Climatic changes observed in recent decades have provided sufficiently favorable conditions for the growth of introduced species of straight standing cedar pines in the south of Magadan Oblast. The results obtained show that cedar pines can be cultivated and used as decorative plantations in the conditions of Northern Priokhotye.

\section{Keywords: Siberian pine, Pinus sibirica, Korean pine, Pinus koraiensis, introduction, fruiting, Northern Priokhotye, Magadan Oblast.}

\section{REFERENCES}

Danchenko, A. M., Beh, I. A., 2010. Cedar Forests of West Siberia. Tomsk, Tomsk State University [In Russian].

Dokuchaeva, V. B., 2011. The Situation with the Introduced Woody Plant Species in Magadan and Its Surroundings, Geology, Geography, Biodiversity and Resources of Russian Northeast : Materials of the FarEastern Regional Scientific Conference Devoted to Memories of the A. P. Vaskovsky and his 100 th Birth Anniversary (Magadan, November 22-24, 2011). Magadan, NESC FEB RAS. 185 [In Russian].

Dokuchaeva, V. B., 2013. Species of the Genus Pinus (Pinaceae) Introduced in Magadan Oblast, Proceedings of the XIII Congress of the Russian Botanical Society and the Conference "Scientific Basis of Protection and Rational Use of the Vegetation Cover of the Volga Basin" (Togliatti, September 16-22, 2013). V. 3. Protection of the Vegetative World. Togliatti: Kassandra, 129-131 [In Russian].

Dokuchaeva, V. B., 2014. The Pine (Pinus sylvestris) Plantings Condition in Magadan Oblast, Vestnik NESC FEB RAS. 2, 88-96 [In Russian].

Dokuchaeva, V. B., Dokuchaev, N. E., 2015a. Species of Fir Trees in the Plantings of Magadan City Environs, Vestnik FEB RAS. 5, 78-82 [In Russian].

Dokuchaeva, V. B., Dokuchaev, N. E., 2015b. The Spruce (Picea, Pinaceae) Plantings Condition in Magadan City Environs, Vestnik NESC FEB RAS. 4, 67-75 [In Russian].

Flora and Vegetation of Magadan Oblast (Checklist of Vascular Plants and Outline of Vegetation), 2010. Magadan, IBPN FEB RAS [In Russian].

Handbook on the Climate of the USSR, 1966, Issue 33, Chukchi National District and Magadan Oblast, Part II, Air and Soil Temperature. Leningrad, Hydrometeorological Publishing House [In Russian].

Ignatenko, M. M., 1988. Siberian Pine (Biology, Introduction, Culture). Moscow, Nauka [In Russian].
Im, S. T., Kharuk, V. I., Lee, V. G., 2020. Migration of the Northern Evergreen Needleleaf Timberline in Siberia in the 21st Century, Sovremennye Problemy Distantsionnogo Zondirovaniya Zemli iz Kosmosa. 17, 1, 176-187 [In Russian].

Krylov, G. V., Talantsev, N. K., Kasakova, N. F., 1983. Siberian Pine. Moscow, Lesnaya Promyshlennost' [In Russian].

Leonova, A. V., 1982. The Museum's Botanic Garden, Kraevedcheskie Zapiski. Magadan, Knizhnoe Isdatelstvo, 12, 210-219 [In Russian].

Man'ko, Yu. I., 2012. Otton Markgraph - Researcher of the Priokhotye Forests, Bulletin of the FEB RAS. 6, 120-126 [In Russian].

Moskalyuk, T. A., 2014. State and Level of Studies of Magadan Oblast Forests, Vestnik NESC FEB RAS. 1, 4654 [In Russian].

Polar Fir Will Settle in Magadan, 1963. Mayak Severa. Newspaper, May 19, 71 (208) [In Russian].

Rysin, L. P., 2011. Siberian Pine Forests of Russia. Moscow, KMK Scientific Press [In Russian].

Scientific-Applied Reference Book on the Climate of the USSR, 1990, Series 3, Long-Term Data, Parts 1-6, Issue 33, Magadan Oblast, Chukotka Autonomous District of Magadan Oblast. Leningrad, Gidrometeoizdat [In Russian].

Siberian Pine Forests, 1985. Novosibirsk, Nauka [In Russian].

Sinelnikova, N. V., Pakhomov, M. N., 2015. Seasonal Life of Nature in the Upper Kolyma Region. Moscow, KMK Scientific Press [In Russian].

Starikov, G. F., 1958. Forests of Magadan Oblast. Magadan [In Russian].

Ushakov, M. V., 2017. Current Changes in the Thermal Regime around Magadansky Nature Reserve, Transactions of the Karelian Research Centre RAS. 4, 93-98 [In Russian]. 